\title{
Root Caries Prevalence in a Group of Brazilian Adult Dental Patients
}

\author{
Marlívia G.C. WATANABE \\ Discipline of Preventive Dentistry, Faculty of Dentistry of Ribeirão Preto, University of São Paulo, \\ Ribeirão Preto, SP, Brazil
}

\begin{abstract}
The aim of this study was to measure the caries prevalence in the root surface in a group of Brazilian adults. The prevalence and their intraoral distribution of caries lesions of root surface were assessed in dental patients ranging in age from 35 to 44 and from 50 to 59 years of age of both sexes $(n=360)$. A total of $98.9 \%$ had root surfaces with gingival recession and $78.1 \%$ had at least one root caries lesion. The prevalence of the disease was analyzed using the Root Caries Index (RCI). The average value was greater for women $(18.6 \%)$ than for men $(13.4 \%)(\mathrm{p}<0.01)$ and similar in both age groups $(\mathrm{p}>0.01)$. The maxillary canines and first premolars and the mandibular molars presented the greatest RCI values. The RCI was greater in the proximal surface of the maxilla and buccal surface of the mandible. We conclude that caries of the root surface are present in the Brazilian population and deserve attention concerning their actual role in the epidemiology of principal oral diseases of the adult population.
\end{abstract}

Key Words: root caries, epidemiology, adult population.

\section{INTRODUCTION}

The world population has suffered numerous alterations and currently the population is aging not only in developed countries but increasingly so in those called the "Third World".

This change in age of the American population and of other developed countries will be followed by a greater permanence of teeth in the mouth until the late years of life, and the objective of dental treatment will have to change to satisfy the demands of specific diseases of late and adult age, including its predominant form of dental caries, i.e., root caries (1). The scientific pendulum of dentistry is swinging towards diseases of this age group because childhood caries have declined and the resources which were directed to the attention of coronary caries in children may now be applied in adults $(2,3)$.

Concerning the less developed countries, the majority of elderly people live in "Third World" countries and demographical projections indicate that from 1980 until the end of the XX century about threefourths of the increase of the elderly population occurred in these countries. This would mean that Brazil would have the sixth most elderly population of the world in absolute terms. It must be noted that the increase in the hope of living when born is desirable for any society, but this must be followed by an improvement in the quality of life for those who have already aged or who are in the process of aging (4).

Taking into consideration these projections and the behavior of caries disease in adults and the elderly in developed countries, the objective was to verify the occurrence of root surface caries in a group of adult Brazilians.

\section{MATERIAL AND METHODS}

Three hundred and sixty patients ranging in age from 35 to 44 years and from 50 to 59 years (100 women and 80 men in each age group) who had their natural teeth were seen at the University clinics (except for Periodontics and Surgery) of the Faculty of Dentistry of Ribeirão Preto, University of São Paulo (Ribeirão Preto, SP, Brazil).

The clinical examination was carried out by only one examiner, in a conventional dental chair, with artificial light and the use of a plain buccal mirror and 
exploratory probe. The Root Caries Index (1) was used for evaluation. This index expresses the proportion of carious and filled root surfaces among the exposed root surfaces to the buccal environment, i.e., with gingival recession, and can be calculated by the following formula: $\mathrm{RCI}=$ No. of surfaces with root caries lesions/ No. of surfaces with gingival recession X 100 .

The condition of each root surface was analyzed according to the following criteria: a) a root surface was considered to have gingival recession when the apical surface of the cemento-enamel junction was visible (5); b) a root surface was considered carious when it presented an area with a darkened appearance, discolored, well-defined, allowing easy penetration of the exploratory probe (6); c) a root surface was registered as filled when it had a restoration, without being judged whether it was an abrasion, erosion or caries result (7); d) conventions for diagnosis were adopted according to Katz (8).

The results were analyzed applying the MannWhitney test and $p<0.01$ was considered to be statistically significant.

Table 1. Mean number of root surfaces with caries, with gingival recession and Root Caries Index according to age and gender.

\begin{tabular}{|c|c|c|c|}
\hline & \multicolumn{3}{|c|}{ Age (years) } \\
\hline & 35 to 44 & 50 to 59 & All \\
\hline \multicolumn{4}{|c|}{ Root Surface Caries (surface) } \\
\hline Male & $3.4(4.1)$ & $5.6(8.7)$ & $4.5(6.9)$ \\
\hline Female & $3.6(3.8)$ & $5.0(6.8)$ & $4.3(5.6)$ \\
\hline All & $3.5(3.9)$ & $5.3(7.7)^{\mathrm{a}}$ & $4.4(6.2)$ \\
\hline \multicolumn{4}{|c|}{ Gingival Recession (surface) } \\
\hline Male & $28.5(19.9)$ & $37.9(19.6)$ & $32.3(20.3)$ \\
\hline Female & $20.9(15.0)$ & $26.7(16.6)$ & $23.9(16.1)$ \\
\hline All & 24.4 (17.9) & $31.7(18.9)^{\mathrm{a}}$ & $28.1(18.7)$ \\
\hline \multicolumn{4}{|c|}{ Mean Root Caries Index* (\%) } \\
\hline Male & $12.1(14.8)$ & $14.7(15.7)$ & $13.4(15.3)^{\mathrm{t}}$ \\
\hline Female & $19.4(18.8)$ & $18.0(16.4)$ & $18.6(17.7)$ \\
\hline All & $16.6(17.5)$ & $16.5(16.2)$ & $16.3(16.8)$ \\
\hline
\end{tabular}

*Average based on individual values. Standard deviation is reported within parentheses.

${ }^{a} p<0.01$ compared to the total of patients aging from 35 to 44 years old (Mann-Whitney).

${ }^{\mathrm{b}} \mathrm{p}<0.01$ compared to the total of female patients (Mann-Whitney).

\section{RESULTS}

The patients presented an average of 12.7 lost teeth. Root surfaces with gingival recession were observed in $98.9 \%$ of the patients. In relation to the prevalence of root surface caries, $78.1 \%$ of the patients presented at least one root caries lesion (women: $81.0 \%$; men: $74.4 \%$ ). The data in Table 1 show that men and women presented similar mean values for the root surfaces affected by disease ( 4.5 and 4.3 , respectively; $\mathrm{p}<0.01)$; however, men had more susceptible surfaces (with gingival recession: 32.3 and 23.9, respectively; $\mathrm{p}<0.01)$. This determined greater values for the RCI for women (18.6\%) than for men (13.4\%). Regarding age, the values of the index were similar for both age groups $(\mathrm{p}>0.01)$.

The Root Caries Index was greater in canines and first premolars in the maxillary arch (Figure 1) and

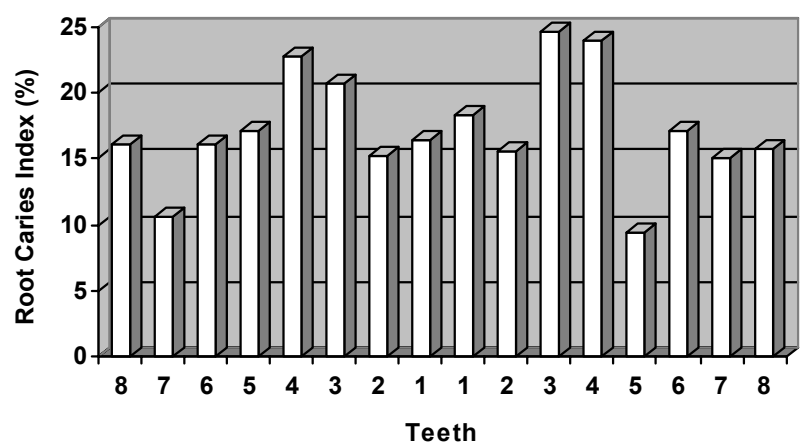

Figure 1. Root caries index according to teeth in the maxillary arch. 1,2 = central and lateral incisors, respectively; 3 = canines; $4,5=1^{\text {st }}$ and $2^{\text {nd }}$ premolars, respectively; $6,7,8=1^{\text {st }}, 2^{\text {nd }}$ and $3^{\text {rd }}$ molars, respectively.

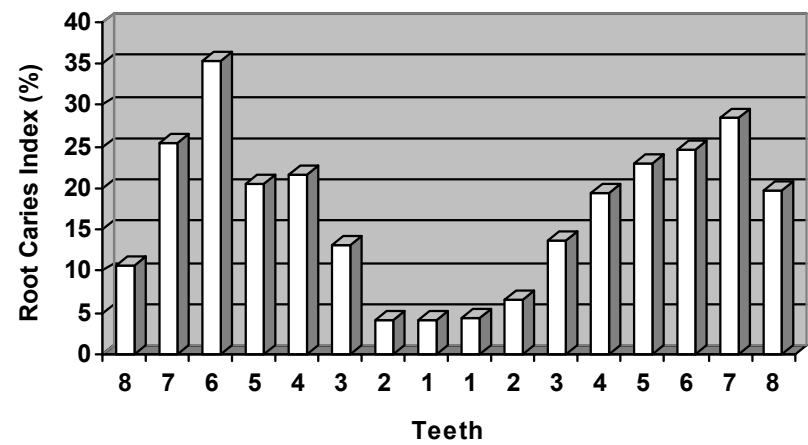

Figure 2. Root caries index according to teeth in the mandibular arch. 1,2 = central and lateral incisors, respectively; 3 = canines; $4,5=1^{\text {st }}$ and $2^{\text {nd }}$ premolars, respectively; $6,7,8=1^{\text {st }}, 2^{\text {nd }}$ and $3^{\text {rd }}$ molars, respectively 
in molars in the mandibular arch (Figure 2).

The buccal surfaces presented more than half of the root caries lesions (55.5\%), followed by distal $(17.3 \%)$, lingual (14.4\%) and mesial (12.7\%). Figure 3 shows the Root Caries Index according to the surfaces in the dental arches. Higher values were noted in the maxilla for proximal surfaces $(25.6 \%)$ and in the mandible for buccal surfaces (24.1\%). Considering the distribution in the mouth as a whole, buccal surfaces presented the highest values (21.2\%) for the Root Caries Index. The lower values of the index were observed for lingual surfaces, not only in the maxilla (12.9\%) and mandible $(4.9 \%)$, but also in the mouth as a whole $(7.7 \%)$.

\section{DISCUSSION}

The large proportion of patients presenting gingival recession observed in this study $(98.9 \%)$ was similar to that reported in other studies $(5,9,10)$. However, the presence of at least one root surface caries lesion varied in the literature compared to $78.1 \%$ in the present study. Some research of patients of similar ages $(7,9,10)$ reported proportions between 63 and $100 \%$. In contrast, other works $(11,12)$ showed less elevated results between 20 and $42 \%$. In terms of the Root Caries Index, which expresses the risk of developing caries disease due to the root surface being exposed to the buccal environment, the observed value among the patients of this study was $16.3 \%$, which is similar to that estimated for populations of industrialized countries,

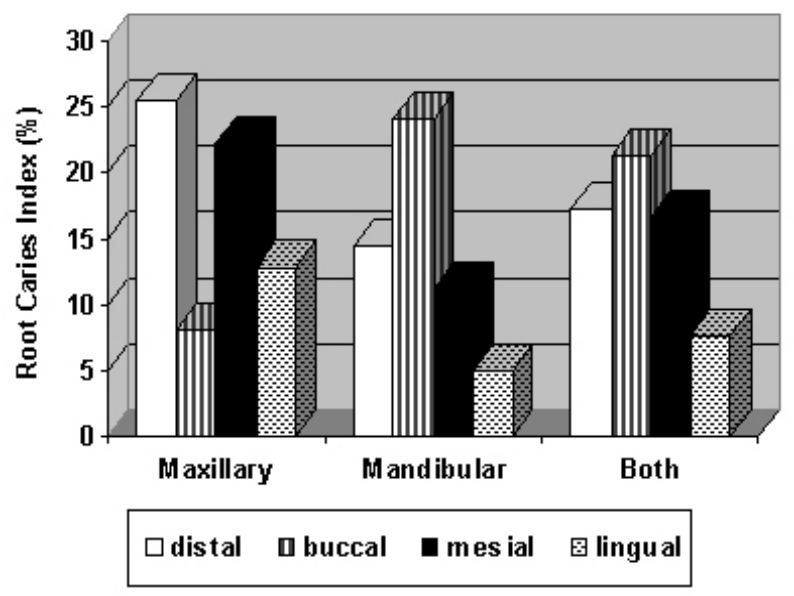

Figure 3. Root caries index according to surfaces and dental arches. i.e., $15-20 \%(12,13)$.

The data of the presence of root surfaces with gingival recession and caries lead us to consider that the examined men had less risk of developing disease than women, as seen in the values of RCI shown in Table 1. Several studies have reported a higher RCI for men $(7,11)$ and other studies have reported the opposite $(11,14,15)$.

The number of surfaces with gingival recession and affected by root caries was greater among patients aging 50 to 59 years of age $(\mathrm{p}<0.01)$, although the RCI had been similar in both age groups $(p<0.01)$. Results demonstrating an increase in the prevalence of the disease with age were also reported in studies of North American (3,12), Asian (16) and European patients $(13,14)$.

When analyzing the RCI according to teeth (Figures 1 and 2), the larger values observed in the molars and premolars in the mandible and canines and premolars in the maxilla, and the smaller values in the mandibular incisors, agree with other studies $(10,14,17)$. In relation to the dental surfaces, similar to that observed in the present study, several authors $(5,14,17)$ reported larger values of RCI in interproximal surfaces in the maxilla and in the buccal surfaces in the mandible.

The results showed that the prevalence of root surface caries deserves attention when considering the epidemiology of the main buccal diseases that affect Brazilian adults.

\section{ACKNOWLEGMENTS}

The author would like to thank Dr. Antônio Galvão Fortuna Rosa for his contribution during the development of this work.

\section{RESUMO}

O objetivo deste estudo foi medir a prevalência de cárie na superfície radicular em um grupo de adultos. A prevalência e a distribuição intra-oral de lesões de cárie de superfície radicular foram avaliadas em um grupo de pacientes odontológicos com idade variando de 35 a 44 e 50 a 59 anos de ambos os sexos $(\mathrm{n}=360)$. Observou-se uma proporção de $98,9 \%$ das pessoas possuindo superfícies radiculares com recessão gengival e 78,1\% apresentaram pelo menos uma lesão de cárie radicular. A prevalência da doença foi analizada utilizando-se o Índice de Cárie Radicular (ICR). O valor do ICR médio foi maior para as mulheres $(18,6 \%)$ que para os homens $(13,4 \%)$ e semelhante em ambas as faixas etárias $(\mathrm{p}>0,01)$. Os caninos e primeiros prémolares na maxila e os molares na mandíbula apresentaram os 
maiores valores para o ICR. Em relação às superfícies, o ICR foi maior nas proximais da maxila e vestibulares da mandíbula. A cárie de superfície radicular atinge grupos da população brasileira e merece atenção quanto ao seu papel atual na epidemiologia das principais doenças bucais que atingem a população adulta.

\section{REFERENCES}

1. Katz RV. Assessing root caries in populations: the evolution of root caries index. J Public Health Dent 1980;40:7-16.

2. Ripa LW, Leske GS. Root surface caries symposium. Gerodontology 1986;5:3-4.

3. Leske GS, Ripa LW. Three-year root caries increments: implications for clinical trials. J Public Health Dent 1989;49:142-146.

4. Kalache A, Veras RP, Ramos LR. O envelhecimento da população mundial. Um desafio novo. Rev Saúde Públ 1987;21:200-210.

5. Fure S, Zickert I. Prevalence of root surface caries in 55, 65 and 75-year-old Swedish individuals. Community Dent Oral Epidemiol 1990;18:100-105.

6. Katz RV. The clinical identification of root caries. Gerodontology 1986;5:21-24.

7. Beck JD, Hunt RJ, Hand JS, Field HM. Prevalence of root and coronal caries in a noninstitutionalized older population. J Am Dent Assoc 1985;111:984-967.

8. Katz RV. Clinical signs of root caries: measurement issues from an epidemiologic perspective. J Dent Res 1990;69:1211-1215.
9. Banting DW, Ellen RP, Fillery ED. Prevalence of root surface caries among institutionalized older persons. Community Dent Oral Epidemiol 1980;8:84-88.

10. Fejerskov O, Luan WM, Nyvad B, Budtz-Jorgensen E, HolmPederson P. Active and inactive root surface caries lesions in a selected group of 60- to 80-year-old Danes. Caries Res 1991;25:385-391.

11. Katz RV, Hazen SP, Chilton NM, Mumma RD. Prevalence and intraoral distribution of root caries in an adult population. Caries Res 1982;16:265-271.

12. Katz RV. Root caries. Is it the caries problem of the future? J Can Dent Assoc 1985;51:511-515.

13. Nicolau B, Srisilapanan P, Marcenes W. Number of teeth and risk of root caries. Gerodontology 2000;17:91-96.

14. Gustavsen F, Clive JM, Tveit AB. Root caries prevalence in a Norwegian adult dental patient population. Gerodontics 1988;4:219-223.

15. Moore PA, Weyant RJ, Etzel KR, Guggenheimer J, Mongelluzzo MB, Myers DE, Rossie K, Hubar H, Block HM, Orchard T. Type 1 diabetes mellitus and oral health: assessment of coronal and root caries. Community Dent Oral Epidemiol 2001;29:183-194.

16. Lin HC, Wong MC, Zhang HG, Lo EC, Schwarz E. Coronal and root caries in Southern Chinese adults. J Dent Res 2001;80:14751479.

17. Katz RV, Newitter DA, Clive JM. Root caries prevalence in adult dental patients. J Dent Res 1985;64:293 (abstract 1069).

Accepted November 25, 2002 